\title{
A Problem-Driven Approach to Education Reform: The Story of Sobral in Brazil
}

\author{
by Tim McNaught \\ Building State Capability, Center for International \\ Development at Harvard University
}

\section{Introduction}

For more than two decades, the Brazilian municipality of Sobral has focused intensively on improving the quality of its public education system; the resulting success has been remarkable. In 2005, the Brazilian federal government started calculating a Basic Education Development Index (IDEB in Portuguese), which measures the quality of education in schools across the country. In the inaugural results in 2005, 1,365 municipalities had a better score for primary education than Sobral. By 2017, Sobral made national news by ranking number one in the entire country for both primary and lower secondary education (Cruz and Loureiro, 2020). These results are even more impressive when considering that Sobral is located in the northeastern state of Ceará, which is the fifth poorest state in Brazil in terms of GDP per capita (Cruz and Loureiro, 2020).

\section{Key Points}

- A diagnostic assessment in 2000 revealed that nearly half of all second graders in Sobral could not read. These results, along with results from a follow-up assessment, marked a turning point in how the municipal government approached education reform.

- In 2001, the government set a goal of 100 percent literacy for children by the end of the second year of primary school. Three years later, over 91 percent of students completing their second year could read text with ease.

- The case of Sobral exhibits many elements that are similar to Problem Driven Iterative Adaptation (PDIA), an approach for solving complex problems. This paper explores the transformation of Sobral's education system through the lens of PDIA, with an emphasis on the reform period from 2000-2004.

How has Sobral achieved such results? According to a 2020 interview with Ivo Gomes, the current mayor of Sobral, "We have reached this position because this is a 23-year-old project that has surpassed changes in mayors and secretaries of education. People think it's magic and it's not. It is persistence and a lot of hard work" (Johnson, 2020). Understanding the success of Sobral requires looking back to the beginning of reform efforts in 1997, when Ivo Gomes' brother (Cid Gomes) began his first term as mayor.

In 1997, the newly elected mayor of Sobral implemented multiple reforms to improve the education system. While enrolment numbers and school buildings improved, many students were still not learning. A diagnostic assessment in 2000 revealed that 48 percent of second graders in Sobral could not read. In early 2001, results from a second assessment of all second, third, and fourth graders also revealed poor outcomes. The results were a wake-up call and revealed a problem that the municipal leadership could not ignore. Instead of hiding the assessment results, the municipal government widely shared them with the community and announced a goal of 100 percent literacy for children by the end of the second year of primary school. Three years later, an assessment showed that over 91 percent of students completing their second year of primary school could read text with ease.

The municipal leadership made many important reforms that were key to this success, including: setting clear targets, improving management both at the Secretariat-level and the school-level, increasing school autonomy and responsibility, 
introducing a new pedagogy, training teachers, and increasing financial incentives to school staff. Another critical reform was the Secretariat of Education's introduction of external assessments of all primary school students, held twice a year. Combined with the other reforms, these assessments resulted in an education system that was constantly learning, iterating, and identifying new ways to improve student literacy.

The case of Sobral exhibits many elements that are similar to Problem Driven Iterative Adaptation (PDIA), an approach wherein problems are key to driving change (Andrews et al., 2015). The PDIA approach relies on reformers to identify problems that matter, break them down into their root causes, identify entry points, act, stop to reflect, and then iterate and adapt their way to a solution. ${ }^{1}$ This process of constant feedback and experimentation by local actors allows for the development of a solution that fits the local context.

This paper explores the transformation of Sobral's education system through the lens of PDIA ${ }^{2}$, with an emphasis on the early reform period of 2000-2004. Many excellent papers have been written, in Portuguese and English, about the case of Sobral; this paper draws heavily on this existing literature. ${ }^{3}$ The paper is also supported by interviews from key individuals who either were closely involved with the reform efforts or have studied them. The paper follows the narrative of the Sobral story, starting in 1997, and uses boxes and other diagrams to view the reform efforts through the lens of PDIA. Finally, the paper explains how the reform efforts grew and scaled over the years, not only within Sobral, but also to other municipalities in Ceará and across Brazil.

\section{Initial Reform Period of 1997-2000}

In 1997, Cid Gomes began his first term as mayor of Sobral and established education as one of the main priorities of his government. Gomes' administration inherited an education system where many principals and teachers were hired based on political interests rather than meritocracy. One of the first reforms made by the municipal leadership in 1997 was to lay off 1,000 teachers who were hired without meeting the necessary technical requirements and to pass a law (Sobral Municipal Law 123, 1997) that defined technical criteria for hiring new teachers (Cruz and Loureiro, 2020).

Another important development that affected Sobral was the creation of FUNDEF, a federal education program which raised funds from federal, state, and municipal governments and redistributed them according to the number of student enrollment (Cruz and Loureiro, 2020). This gave an additional incentive to the municipality to increase enrolment and "between 1996 and 1999, student registration at the municipal network grew from 9,000 to 17,000" (Cruz and Loureiro, 2020). Sixty percent of the funding was set aside for teachers and the remaining funds were used for improving the infrastructure of the schools, uniforms, and school meals (Becskeházy, 2018b).

During the period of 1997-2000, the municipal government built four new schools, expanded another four, and renovated 26 of the largest schools in its network (Maia, 2006). In addition, the number of books and other teaching materials available at school increased significantly (Maia, 2006). In other words, the municipality invested heavily in school inputs and saw significant increases in enrolment during Gomes' first term in office. But were the students learning?

\section{Finding a Problem that Matters}

In July 1999, a report by the Carlos Chagas Foundation, commissioned by the Ayrton Senna Institute, revealed that a "substantial contingent" of students in the early years of elementary school in Sobral were not able to read words, news that was surprising for the municipal leadership (Becskeházy, 2018a,b). To get a better understanding of the problem, the Secretariat of Education hired a team led by Edgar Linhares, a retired professor from the Federal University of Ceará and a specialist in literacy, to carry out a diagnostic assessment of the reading level of second graders in Sobral (Maia, 2006; INEP, 2005). The assessment, which took place in 2000 and was based on a sample of 75 percent of students who were completing second grade, revealed that 48 percent of second graders could not read (Coelho, 2005). For this assessment, the definition of "cannot read" is when the student "cannot recognise any sound in the words, even if he/she

\footnotetext{
1 See PDIA Toolkit: https://bsc.cid.harvard.edu/PDIAtoolkit

2 See Samji and Kapoor (2022) for another case study on education reform told through the lens of PDIA.

${ }^{3}$ For further reading about Sobral, see the following RISE Insight Note and blog.
} 
recognises the name of the letters" (INEP, 2005). ${ }^{4}$ After all the investments made in the schools and the improvements in enrolment, the municipal leadership was not expecting such a poor result.

In 2000, Cid Gomes was re-elected for a second term as mayor of Sobral, with his mandate to begin in January 2001. Gomes decided to appoint his brother, Ivo Gomes, to be the new Secretary of Education in his cabinet. To understand the extent of the problem, the municipal leadership asked Linhares' team to do another reading assessment at the end of 2000. This time, they assessed all students entering second, third, and fourth grade, meaning "close to 12 thousand students" (INEP, 2005). The results for this second assessment came out in early 2001 and showed that 60 percent of new second graders, 40 percent of new third graders, and 20 percent of new fourth graders did not know how to read (INEP, 2005).

What had started as a surprising finding in a foundation's report had turned into a significant illiteracy problem, backed by extensive and conclusive data. It was an undeniably important problem as literacy is the foundation of learning. Without being able to read, students have difficulty in advancing to learning other subjects. Illiteracy results in higher dropout rates and students being held back a grade. Ultimately, this impacts what future careers and quality of life students will have. Andrews et al. (2015) call this type of problem that "motivates and drives change" a "good problem" as it "cannot be ignored and matters to key agents."

The 2000/2001 assessments marked a turning point. According to Sumiya et al. (2017), "without this data, the managers responsible for conducting the municipality's educational policy believed that they were doing a good job, mainly because they increased teachers' salaries and built beautiful schools. From the assessment feedback, the policy entrepreneur started to face the illiteracy problem differently and began to act strongly to eradicate it." The municipal leadership decided to make literacy a key issue of Gomes' second term. This was cemented by the government setting out two priority goals: ${ }^{5}$

1. Ensuring literacy for all students at the end of their second year (seven-year-olds)

2. Remedial literacy for all older students who had not yet learned to read

The municipal leadership knew that making change would require the support of teachers, principals, and parents. So instead of hiding the poor results of the assessments, "the mayor in Sobral went on radio stations to communicate the results to all citizens. The message was clear: even though the school buildings were renovated, students were not learning. Everyone should know about this failure and should take responsibility for learning." (Cruz and Loureiro, 2020). The Secretariat of Education, including Ivo Gomes, the newly appointed Secretary of Education, held meetings with families to explain the problem and to gain support from parents to help their children learn.

\footnotetext{
66

During the meetings, it was common to see fathers and mothers claiming that the school was 'very good' or 'excellent'. Given these statements, the Municipal Secretary used to ask: 'How can the school be good if it's not teaching your children?' The meetings were not aimed at pinpointing the culprits. Nobody said 'the problem is the principal or the principal, the teacher or teacher', but 'everyone is responsible.' The idea was to reinforce the need for a transformation that would be possible only with the participation of everyone. This process encouraged community participation. (INEP, 2005).
}

Problem construction is the first step in the PDIA process, where "the focal problem needs to reflect on a performance

\footnotetext{
${ }^{4}$ The assessment also identified the reading level of students, starting with those that could read syllables, then words, then sentences, and finally full text. Research from Abadzi (2006) highlights that this process of recognising sounds and reading words must be practiced and "automatised" before students can read for meaning. See RTI International (2015) for a further discussion on early grade reading assessments.
}

${ }^{5}$ See Maia (2006). 
deficiency that cannot be denied or ignored and that matters to key change agents" (Andrews et al., 2015). This aligns well with what happened in Sobral. ${ }^{6}$ The municipal leadership had identified a problem (primary school students are not learning how to read) that was clearly important and could not be ignored. The student assessments were essential data for defining the extent of the problem while the goal of having every student able to read by the second year of primary school was clear and easy to understand. Using the language of PDIA, it allowed everyone to understand what the problem would look like when it was solved (Andrews et al, 2015). The assessment data also allowed the leadership to build support from parents, teachers, and principals and get them to care more about the problem. Box 1 shows the key questions used in the PDIA problem construction process and what it could have looked in Sobral in early 2001.

\section{Box 1: Problem Construction for Sobral}

\section{What is the problem?}

Primary school students are not learning how to read.

\section{Why does it matter?}

Literacy is the foundation of learning. A diagnostic assessment revealed that 48 percent of second graders are unable to read basic syllables.

\section{Why does it matter?}

Without being able to read, students will have difficulty in advancing to learning other subjects. Illiteracy results in higher dropout rates and results in students being held back.

\section{Why does it matter?}

When students do not learn, this can limit their future earnings, career options, and quality of life. Also, all children should have the right to learn, regardless of their socioeconomic status.

\section{To whom does it matter?}

Students and the municipal government.

\section{Who needs to care more?}

Teachers, principals, and parents.

5. How do we get them to give it more attention? (How do we measure it or tell stories about it)

Sharing results of the diagnostic with everyone, including going on the radio and meeting with families to explain the situation to them. Doing more assessments to better understand the problem at the school, classroom, and student levels.

6. What will the problem look like when it is solved?

All students completing their second year will be able to read and all students in older grades will get the support they need to learn how to read. By doing assessments every six months, we will be able to set targets for each school and monitor improvements.

Sources: Section 1 of the PDIA Toolkit; INEP, 2005; Maia, 2006

\section{Breaking Down the Problem}

In order to address the problem, the municipality formed a leadership team, including: Ivo Gomes (Secretary of Education), Izolda Cela (Undersecretary of Education), Joan Edesson de Oliveira (initially Middle School Coordinator and later Superintendent), and three area coordinators (Elementary Education, Early Childhood Education, and Youth and Adult Education). The team was advised by Edgar Linhares, who designed and implemented the diagnostic

\footnotetext{
${ }^{6}$ It is important to note that the authorities in Sobral only began this problem-driven approach as Gomes entered his second term as mayor. During his first term, the focus was largely on inputs (new schools, books, and teaching materials) and increased enrolment. It was only after it was clear that these efforts were not leading to improved learning outcomes that the authorities were open to trying a new iterative approach.
} 
assessments. This team was responsible for defining strategies to overcome the literacy crisis and was provided with strong political support from the mayor.

The second step in the PDIA process is problem deconstruction, which takes a complex problem and breaks it down into its root causes. This can turn a complex problem "into smaller, manageable parts", which "empowers practical thinking about where real reform can begin in the short run (Andrews et al., 2015). One of the main tools used for this step is a fishbone diagram, which allows groups and teams to visualise the problem together and create shared understandings of the problem, with each large "bone" being an individual cause of the problem while the smaller bones are sub-causes. Box 2 shows how the fishbone diagram could have looked for Sobral in early 2001.

\section{Box 2: Problem Deconstruction or Fishbone Diagram for Sobral}

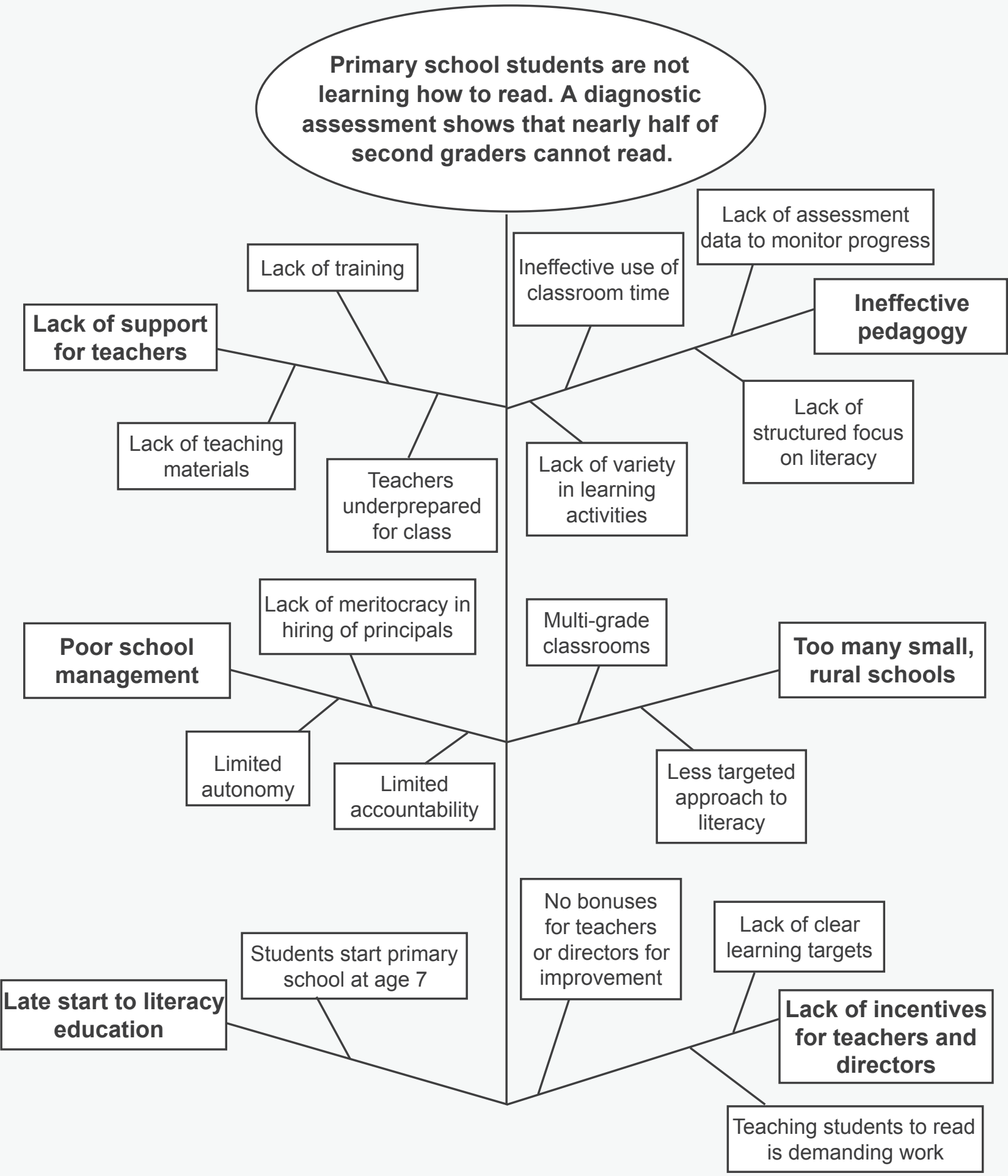




\section{Identifying Multiple Entry Points}

The fishbone diagram in Box 2 highlights six main causes of the problem, with several underlying sub-causes. The third step of the PDIA process is sequencing or change space analysis, which identifies that "each cause and sub-case is essentially a separate-albeit connected-point of engagement." There are three factors that affect the "space for change" in each area, and these are:

- Authority, which "refers to the support needed to effect reform or policy change or build state capability (political, legal, organisational, and personal)."

- Acceptance, which "relates to the extent to which those who will be affected by the reform or policy change accept the need for change and the implications of change"

- Ability, which "focuses on the practical side of reform or policy change, and the need for time, money, skills, and the like to even start any kind of intervention" (Andrews et al., 2015).

In early 2001, there were two causes that were immediately tackled. The first was "late start to literacy education." Students in Sobral entered primary school at the age of seven, which was when literacy education began. In March 2001, Sobral Municipal Law 294 was passed, which expanded primary education to start at age six (Becskeházy and Louzano, 2019).

The new first grade for six-year-olds was called "basic" first grade, while the grade for seven-year-olds was called "regular" first grade. This reform was essential as it started literacy education a year earlier, giving the students and teachers an additional year to train to achieve literacy. In terms of the Triple-A analysis, this was an area that had large authority (there was a legal and political basis to act), large acceptance (parents and teachers were relatively open to the change), and large ability (the municipality had the money and staffing to implement the reform). Given the large levels of authority, acceptance, and ability, the municipality was able to have what Andrews et al. (2015) refer to as a "quick win" for starting its literacy reform efforts.

The second cause that was immediately addressed was "too many small, rural schools." A problem that was long recognised by the Gomes administration was that there many small, rural schools in Sobral that did not have sufficient resources to effectively teach the students. Students were placed in multi-grade classrooms and did not get the focused support needed to effectively learn. With an organised network of larger schools, it would be possible to provide better infrastructure and a better learning environment for students with appropriate grade allocation. According to Maia (2006), "in early 2001, the number of municipal schools was reduced from 96 to 38." While this reform had large levels of authority and ability, it initially did not have large acceptance. Many parents did not want their children to travel so far to the new hub schools (Cruz and Loureiro, 2020). The municipality arranged transportation for the students and met with the communities to explain the advantages of the new management; "when the results of the policy gained visibility and the population began to see an improvement in the quality of schools, the initial resistance was losing ground to acceptance and respect" (INEP, 2005). This as an example of how a reformer can build acceptance for a new policy. 
Box 3: Triple-A Change Space Analysis for Sobral

Cause 1: Late start to literacy education

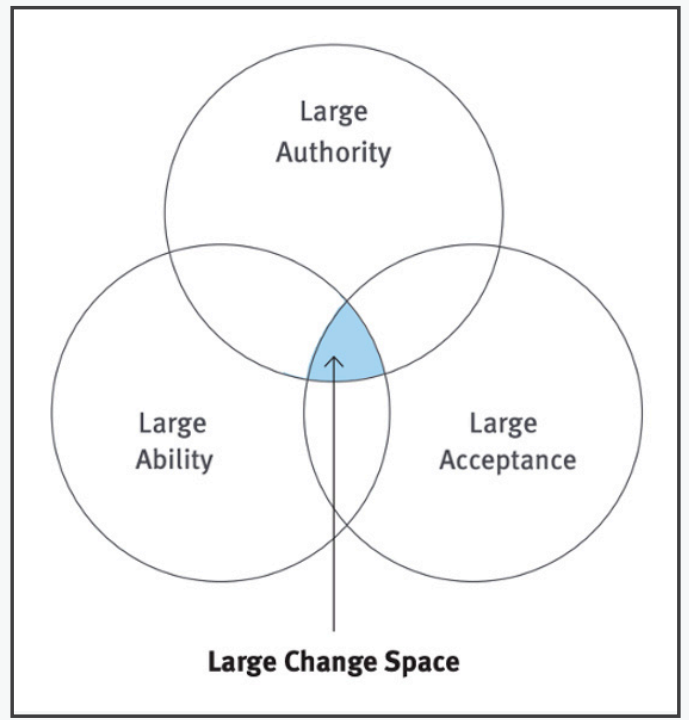

Given the relatively large levels of authority, acceptance, and ability, the municipality was able to have what Andrews et al. (2015) refer to as a "quick win" by starting literacy education a year earlier in primary school.
Cause 2: Too many small, rural schools

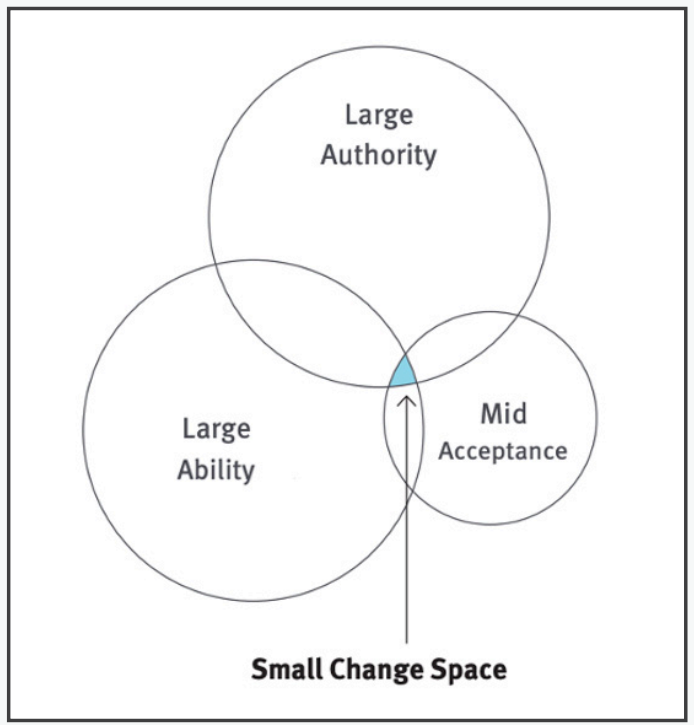

While there were initially low levels of acceptance from parents for consolidating the school network, the municipality arranged transportation for the students and met with the communities to explain the advantages of the new management. This created enough acceptance (illustrated as "mid acceptance") to begin the reform. As positive results came out, this helped build even more acceptance among the community.

\section{Making Strategic Reforms throughout the Entire System (2001-2004)}

Cruz and Loureiro (2020) conclude that "there was no silver bullet in the education reform in Sobral." In other words, there was no single solution that was ultimately responsible for the improvement in the education system. Instead, many different policies were implemented over many years. Sumiya (2015) consolidates the key educational reforms made during 2001-2004 into four strategic fronts: institutional management (at the Secretariat-level), strengthening school management (at the school-level), pedagogical strengthening, and professional incentives and teacher appreciation. In this section, we briefly cover some of the key ideas and actions taken within each area. The following section then explains how these reforms came together to build a system that was constantly learning, iterating, and adapting to meet the literacy goals of the municipality. Instead of attempting to solve a complex problem with a single "solution", the PDIA approach encourages an experimental and iterative process where "multiple solution ideas are identified and put into action" (Andrews et al., 2016).

\section{Institutional management (at the Secretariat-level)}

From 2001-2004, Sobral was one of 47 municipalities participating in an educational management programme called Escola Campeã (Champion School), which was created by the Ayrton Senna Institute and the Bank of Brazil Foundation (Hattge, 2007). One of the requirements of the programme was to create a "School Superintendence", a team within the Secretariat of Education which was responsible for being the main point of contact between the Secretariat of Education and the schools. The idea was for the School Superintendence team to visit each school at least twice a month to meet with the principal, monitor the progress of the school, and provide support. In 2002, Joan Edesson de Oliveira was made the Superintendent of the Secretariat of Education in Sobral and visited all 38 schools 
himself. His team expanded over time, allowing the allocation of schools to specific team members, and to increase the number of visits. There were a set of indicators that the Superintendence team used to monitor each school, including: student and teacher attendance, functioning infrastructure (bathrooms, cafeteria, classrooms), teaching plans, and learning assessments, which created a "culture of monitoring results based on indicators" (INEP, 2005).

The other key institutional reform was the implementation of periodic external assessments of every student (in Grades 1-4) in every school in Sobral. The assessments were initially held once a year, but were then implemented every six months, at the end of each semester (INEP, 2005). This allowed schools to make mid-year course corrections to change teaching strategies that met the needs of the students. The assessments also allowed schools to know which teachers needed more support. Eventually, many schools developed their own monthly assessments to monitor the progress of their students (INEP, 2005). According to Joan Edesson de Oliveira, instead of blaming poor results on external problems (poverty, violence, lack of funds), the assessments helped shift the discussions to look at what could be changed within the school to help students learn.

We adopt our own assessment at the school. We have instruments that allow you to see
what the student has learned each month. If he didn't learn, we take action. Our goal is to
reach 95 percent of literate students. Next year, let's get better. Let's do a better job every
year. - School Principal (INEP, 2005)

\section{Strengthening school management (at the school-level)}

From 2001, there were three main changes that strengthened school management. First, principals were now selected based on technical, not political criteria. In 2001, two-thirds of former principals were replaced (Maia, 2006). Second, "pedagogical coordinators" were inserted directly in the schools. They were also selected by merit and each pedagogical coordinator would monitor the progress of students and assist the teachers in delivering the learning materials. There was one pedagogical coordinator for every 350 students and the school principal was allowed to select which pedagogical coordinators they wanted to work with, based on a list of approved professionals (INEP, 2005). Finally, the schools were given more financial autonomy. Before, principals would have to make requests to the Secretary for every small expenditure, which took up a lot of the time of the principal and resulted in delays (INEP, 2005). This increase in autonomy was accompanied by an increased responsibility of school principals to produce results.

\section{Pedagogical strengthening}

The Secretariat of Education knew that it had to strengthen the teaching methodologies and learning materials used in the classroom. The previous textbooks were hardly used by teachers as they were too difficult for the students (Sumiya, 2015). The Secretariat hired the team of Edgar Linhares, who carried out the original diagnostic assessment in 2000, to prepare new learning materials for the teachers (Maia, 2006). Linhares' team developed detailed literacy teaching material, set weekly and monthly learning goals, and provided eight hours of training to the teachers each month (Sumiya, 2015). The trainings were originally held on the weekends, but the teachers were tired, so the Secretariat provided substitute teachers in order to offer the training during work hours (INEP, 2005). This allowed the teachers to go over what was done the previous month, what worked, what they were struggling with, and to plan for the next month.

\section{Professional incentives and teacher appreciation}

In Sobral, the Secretariat of Education introduced financial incentives to further motivate professionals working in the schools. The "Escola Alfabetizadora Prize" was created in 2001, "a monetary incentive for teachers, pedagogical coordinators, and school principals if the school achieves its learning goals" (Cruz and Loureiro, 2020). In addition, literacy teachers were given a 30 percent salary bonus if they met their literacy goals; by 2003, the rules were changed so that the bonus could be reduced by 25 percent or 50 percent, depending on how far off student results were from the literacy target, but the teacher could receive the full bonus if he/she achieved the target the next year (INEP, 2005).

In 2001, I didn't have a satisfactory result, but the principal trusted me and, thank God, not only him, but the whole team, the coordination team, the management team, everyone, I got a great result in 2002. Today I feel happy and I feel that I am cooperating, that I am helping to transform this country, because the children who are passing through our hands are the future of this country. 


\section{Building a System Based on Assessments, Iteration, and Learning}

At the center of Sobral's education reform were the external student assessments. Conducted at the end of every semester, this data gave an objective view of how every school, teacher, and student was doing in relation to the set targets. When the results of each new assessment were ready, the following meetings took place, in this order (INEP, 2005, pgs. 45-46):

1. The Secretariat of Education held meetings with all school principals to share the results of schools across the entire municipality

2. The School Superintendence team conducted visits to each school to help the principals understand and analyse the results of their school

3. The principal then discussed the data with their pedagogical coordinators, identifying the main problems to be solved, which teachers need the most help, and where it was most necessary to make changes

4. Finally, the principal and pedagogical coordinators held a meeting with all the teachers in the school. At this meeting, the pedagogical coordinator listened to the ideas of the teachers and they co-created strategies to overcome learning gaps.

Perhaps even more important than these meetings were the regular meetings that happened in between the assessments. These included the following (INEP 2005):

- Weekly meetings at each school between the principal and pedagogical coordinators, to ensure, throughout the year, the monitoring of student learning and to support teachers and administrators in their work.

- $\quad$ Twice-monthly meetings at each school between the principal, pedagogical coordinators, and teachers, to ensure, throughout the year, the monitoring of student learning and to support teachers and administrators in their work.

- Monthly training of teachers to go over what was taught the previous month, what worked, what they were struggling with, and to plan for the next month.

- $\quad$ Periodic visits of the pedagogical coordinators to classrooms to observe teachers working and to provide support and suggestions for improvement.

- Weekly meetings between all school principals, coordinated by the School Superintendence team, to monitor progress of schools.

- $\quad$ Twice-monthly visits from the School Superintendence team to each school, to meet with the principal, monitor progress, and offer support.

A key component of PDIA is "experimental iteration", "where policymakers and would-be reformers can try new ideas out, learn what works and why, adapt ideas, and repeat the process until a solution is found" (Andrews et al., 2016). This type of approach works best with complex challenges, where there is a vision of what success looks like, but it is not at all clear how to achieve that result. After each iteration, teams stop to reflect and ask a few basic questions: i. "What did we do?"; ii. "What did we learn?"; iii. "What are we struggling with?"; and iv. "What's next?" (PDIA Toolkit).

In the case of Sobral, the entire educational system revolved around reaching the literacy targets. They were clear targets that were easy to explain to everyone in the system. According to Coelho (2006), "the external assessment was configured as an essential management tool for monitoring and carrying out the necessary interventions for achieving the goals. The results (obtained through universal criteria, sufficiently objective, and with a satisfactory level of control) went to the analysis table, where the construction (and deconstruction) of hypotheses culminated in the definition of strategies to face the challenges, both from the point of view of the network and of each school, each class, each student." These meetings following the release of the assessment results were important for taking stock and giving everyone in the system the chance to look at what was done, what was working, where there were still challenges, and to share ideas on what to do next. Mid-year assessments allowed schools to come up with ideas to improve outcomes in the next semester. In between the assessments there were also many meetings taking place that allowed for reflection, iteration, and adaption. Figure 1 illustrates the iterative system created in Sobral. ${ }^{7}$

\footnotetext{
${ }^{7}$ See Muralidharan and Singh (2020) for an example of a school management programme that failed in India. The paper shows that simply implementing assessments, action plans, and follow-up meetings does not guarantee success in learning outcomes. What might set the case of Sobral apart is that the reform started with a clear definition of the problem and a political commitment to change. The weekly meetings and classroom visits were also not seen as "checkbox" activities; there was substantial accountability for achieving results and corresponding incentives for staff.
} 
Figure 1: Cycle of iteration, learning, and action in Sobral

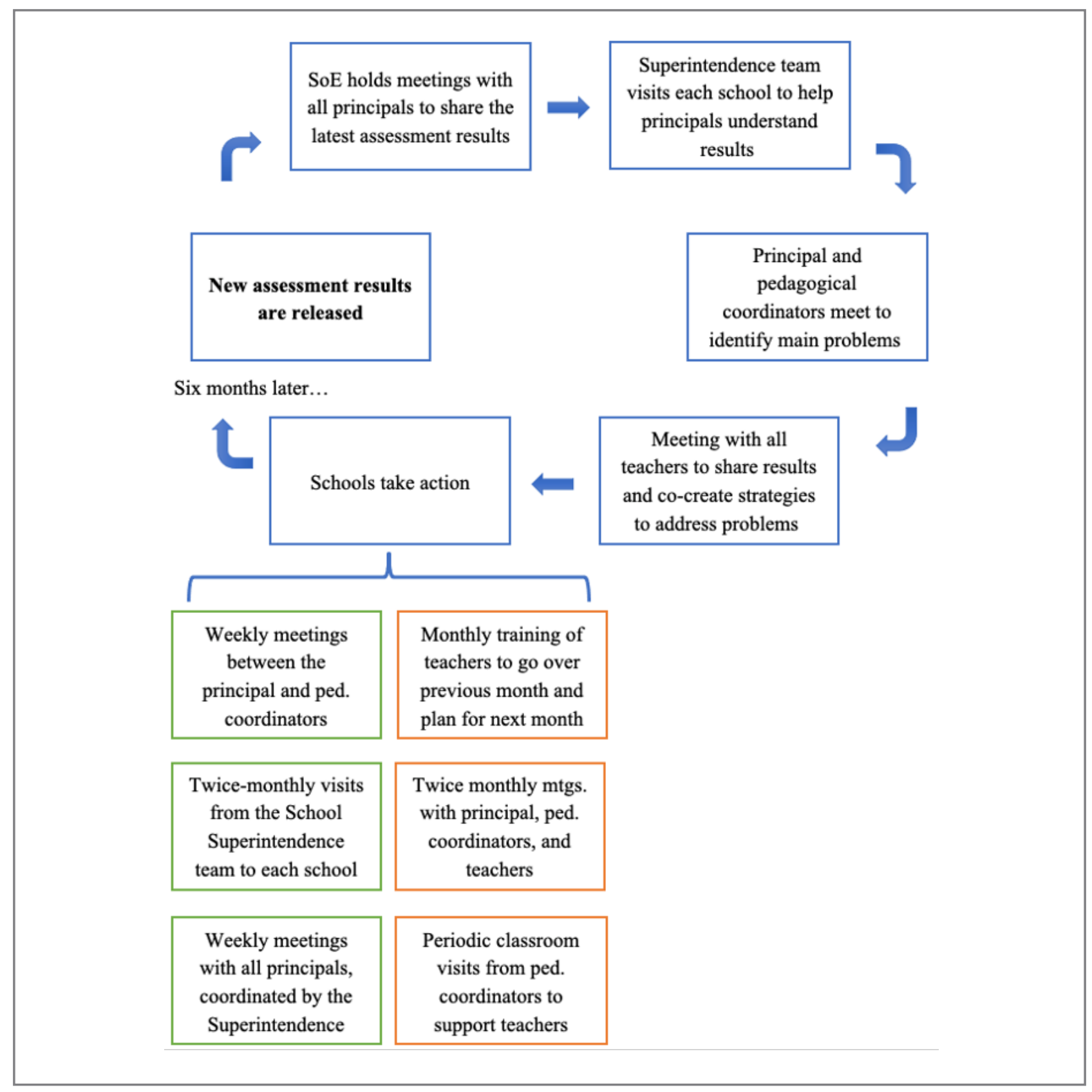

Source: Author's illustration, adapted from INEP, 2015.

The structure of the meetings might give the illusion that the reform efforts were entirely planned and controlled from the top down. However, the system encouraged experimentation all the way down to the classroom level and the sharing of these ideas, as long as each actor in the system remained committed to achieving the overall literacy goals. For example, teachers were given very detailed lesson plans for each classroom. However, "what was found when analysing and discussing the evaluation results with the school pedagogical teams is that the common trait of successful teachers was an attitude of acceptance of the proposed method, properly tempered with autonomy and creativity. Those who resisted the method but did not propose alternatives, and those who followed it as a rigid prescription had the poorest results" (Maia, 2006). Teachers were thus encouraged to use the lesson plans as a foundation, but to incorporate their own unique talents and ideas into each classroom lesson.

As noted earlier, the school directors were given more autonomy, but also were held more accountable for results. In the beginning, the frequent visits from the Superintendence teams to the schools received some resistance from the principals and teachers, as they felt they were being inspected (INEP, 2005). However, the principals soon realised 
that the Superintendence team was fundamental for helping the school to monitor its progress and come up with solutions to solve various problems (INEP, 2005). Joan Edesson de Oliveira, the first Superintendent of the Secretariat of Education in Sobral, noted that there was a shared responsibility that developed between the school principals and the School Superintendence team. The principals knew that they needed to deliver results, but they also knew that the Superintendence team was there to support them.

\section{Improving literacy rates}

Figure 2 shows the evolution of literacy rates in Sobral from 2001-2004 for students in the first two years of primary school (basic first grade and regular first grade). In 2001, only 33.7 percent of 6 -year-olds could read sentences and by 2004, this number increased to 88.9 percent. For 7-year-olds, the percentage of students who could read text with ease increased from 49.1 percent in 2001 to 91.7 percent in 2004.

Figure 2: Evolution of literacy rates in Sobral-(2001-2004, percentage)

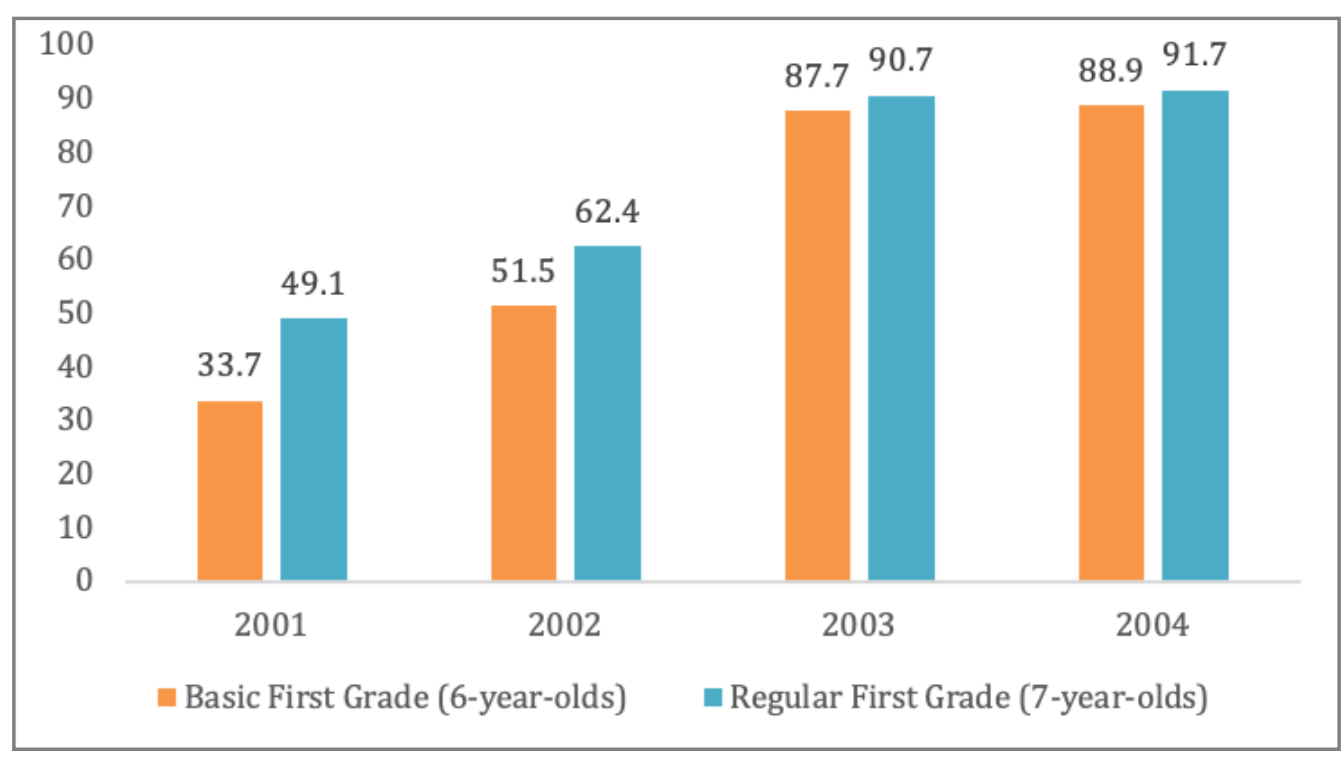

Source: Maia, 2006. For basic first grade, the "literacy rate" includes students who can read text or sentences with ease. For regular first grade, it only includes students who can read text with ease. See Maia (2006, pg. 132) for a complete breakdown.

\section{Building Capabilities in Sobral and Beyond}

Sobral built a lot of capabilities over the period of 2001-2004, which allowed the municipality to become more ambitious with its goals and responsibilities. This is seen particularly with the external assessments. Between 2001-2004, the external assessments were contracted out to an independent team. According to Cruz and Loureiro (2020), "from 2005 onwards, the municipality assumed the design and implementation of assessments and in 2009 it established an external unit (Casa da Avaliação) to manage all municipal evaluations." While the municipality continued to assess literacy in early grades, the system has now expanded to test learning outcomes in mathematics and Portuguese (Cruz and Loureiro, 2020). Literacy is still seen as a foundational skill, but there is more emphasis on students learning materials in other subjects now. Sumiya (2019) notes that the Secretariat of Education has set its targets higher and now aims for Sobral's education network to be one of the best in Latin America.

The story of Sobral's success has spread far across Brazil and beyond. Andrews et al. (2016) explain the concept of "positive deviance" as "ideas that are already being acted upon in the change context (they are thus possible), and that yield positive results (solving the problem, and thus being technically correct), but are not the norm (hence the idea of deviance)." As Sobral's success grew, many municipalities in Ceará began to see Sobral as a possible example of positive deviance. While no municipality in Ceará has the same initial conditions as Sobral, a municipality in Ceará likely has more in common with Sobral than a municipality in Finland or even in the south of Brazil.

Elements of Sobral's reform made their way to the state government level in Ceará when Cid Gomes was elected governor of Ceará in 2006. Starting in 2007, the state government under Gomes implemented "The Program to Achieving Literacy at the Right Age", which placed literacy at Grade 2 as a state-wide goal and provided new lesson materials and training to teachers to support this goal (Evans and Loureiro, 2020). In addition, from 2007, Ceará 
began implementing an annual literacy assessment of all second graders in Ceará (Spaece-alfa), which also had roots from the experience of Sobral (Becskeházy, 2018a). Ceará has also shown impressive improvement in its education results over the last two decades. As of last year, Ceará's "combined reading and math outcomes adjusted for its economic status are the highest in the entire country at both the fifth and ninth grade levels" (Evans and Loureiro, 2020). In 2018, the Associação Bem Comum (Common Good Association) began a new programme, in partnership with the Lemann Foundation, to support municipalities across Brazil to learn from and implement education management practices based on the experiences of Sobral and Ceará. ${ }^{8}$

\section{Conclusion}

Overall, the case of Sobral is an example of a reform that was truly problem-driven. The assessments in 2000/2001 drew attention to a significant literacy problem that received full attention from the municipal leadership. By setting a clear target of literacy for all second-year students, the entire education system understood the problem and what it would look like solved. The problem was then tackled by breaking it down into several smaller causes. A new pedagogy was developed, teachers were trained, principals were hired based on merit and given more autonomy, financial incentives were created, a Superintendence team was formed to monitor and support schools, and an external literacy assessment of all students twice per year was established .

The objective assessment data allowed all actors across the system to monitor their progress towards solving the problem. The varied reforms worked together to create a culture of experimentation, iteration, reflection, and accountability. Results were analysed and ideas for improvement were shared between teachers and across schools. A spirit of shared responsibility developed between school staff and with the Secretariat of Education. And by 2004, over 91 percent of second-year students could read text with ease. The goal of 100 percent literacy remained, but the Secretariat of Education was now able to focus on other sticky problems as well, such as low learning in Portuguese and mathematics. By addressing the illiteracy problem, Sobral's education system had built new capabilities and was now more capable than ever to work on solving future problems. 


\section{References}

Abadzi, Helen. 2006. Efficient Learning for the Poor: Insights from the Frontier of Cognitive Neuroscience. Washington, DC: World Bank. https://openknowledge.worldbank.org/handle/10986/7023

Andrews, Matt, Lant Pritchett, and Michael Woolcock. 2015. "Doing Problem Driven Work" Center for International Development at Harvard University. CID Working Paper No. 307

Andrews, Matt, Lant Pritchett, and Michael Woolcock. 2016. "Doing Iterative and Adaptive Work" Center for International Development at Harvard University. CID Working Paper No. 313

Becskeházy, Ilona. 2018a. "Institucionalização do Direito à Educação de Qualidade: O caso de Sobral CE" Universidade de São Paulo.

Becskeházy, llona. 2018b. "Sobressaltos ou fortuna: As idas e vindas para tentar tirar a educação da idade das cavernas em uma terra desolada" ENAP. Casoteca de Gestão Pública.

Becskeházy, Ilona and Paula Louzano. 2019. "Sobral: A case of educational success in the Semiarid Northeast" ComCiencia.

Coelho, Isolda Cela Arruda. 2005. "O excepcional modelo de educação da cidade de Sobral/ CE” UNDIME. https:// undime.org.br/noticia/o-excepcional-modelo-de-educacao-da-cidade-de-sobral-ce

Evans, David and Andre Loureiro. 2020. Getting Education Right. State and Municipal Success in Reform for Universal Literacy in Brazil. World Bank Group.

Hattge, Morgana Domênica. 2007. "Escola campeã: estratégias de governamento e auto-regulação" UNISONOS.

INEP. 2005. "Vencendo o desafio da aprendizagem nas séries iniciais: A experiência de Sobral/CE" (No 1; Projeto Boas Práticas na Educação). Instituto Nacional de Estudos e Pesquisas Educacionais Anísio Teixeira (INEP).

Loureiro, Andre, and Louise Cruz. 2020. "Achieving World-Class Education in Adverse Socioeconomic Conditions : The Case of Sobral in Brazil.” World Bank. https://openknowledge.worldbank.org/handle/10986/34150.

Johnson, Sarah. 2020. "People think it's magic': how one of Brazil's poorest cities gets its best school results" The Guardian. 25 March 2020. https://www.theguardian.com/world/2020/mar/25/people-think-its-magic-how-one-of-brazilspoorest-cities-gets-its-best-school-results

Maia, Maurício Holanda. 2006. "Aprendendo a marchar: Os desafios da gestão municipal do ensino fundamental e da superação do analfabetismo escolar" [Tese de Doutorado, Universidade Federal do Ceará]. http://www.repositorio.ufc. $\mathrm{br} / \mathrm{handle/riufc/3652.}$

RTI International. 2015. Early Grade Reading Assessment (EGRA) Toolkit, Second Edition. Washington, DC: United States Agency for International Development.

Sumiya, Lilia Asuca, Maria Arlete Duarte de Araujo, and Hironobu Sano. 2017. "A Hora da Alfabetização no Ceará: O PAIC e suas Múltiplas Dinâmicas." Education Policy Analysis Archives/Archivos Analíticos de Políticas Educativas, vol. 25, pp.1-30. Redalyc, https://www.redalyc.org/articulo.oa?id=275050047029

Sumiya, Lilia Asuca. 2019. Sobral e a garantia da aprendizagem de todas as crianças. São Paulo: Fundação Tide Setubal. 


\section{Acknowledgements}

The author would like to acknowledge the excellent research assistance of Julia Tami who contributed to the literature review, organised and conducted interviews, and provided helpful comments and insights on the education sector in Brazil. Special thanks to Joan Edesson de Oliveira, Veveu Arruda, Silvia Monteiro, Julio Cavalcante, and Caio Poli for sharing their knowledge about the case of Sobral. Finally, the author would like to thank Salimah Samji, Marla Spivack, Lant Pritchett, and Barbara Bruns for reviewing the paper and providing helpful feedback.

Tim McNaught is an international development consultant. He previously worked as a Research Fellow at the Center for International Development at Harvard University and as an economist at the Ministry of Finance in Timor-Leste. He developed his strong interest in economic development while serving as a United States Peace Corps Volunteer in Azerbaijan. Tim holds a Master in Public Administration in International Development (MPA/ID) from the Harvard Kennedy School and a Bachelor of Arts in Economics from the University of Miami.

Citation:

McNaught, T. 2022. A Problem-Driven Approach to Education Reform: The Story of Sobral in Brazil. RISE Insight 2022/039. https://doi.org/10.35489/BSG-RISE-RI_2022/039 